\title{
Environmental Paradigms and Organisations with an Environmental Mission
}

\begin{tabular}{|l|l|}
\hline \multicolumn{2}{|l|}{ Authors listed in alphabetical order } \\
Lecturer in Strategic Management & Prof. Jan Bebbington \\
Griffith Business School, & Professor of Accounting and Sustainable \\
Room 1.49, Building N16 & Uevelopment, \\
Nathan Campus & University of St Andrews, \\
Griffith University & Gateway Building \\
170 Kessels Road & St Andrews, Fife, KY16 9SS, UK \\
Nathan, QLD 4111 & T: +441334462348 \\
Australia & F: +441334463949 \\
T: +61 737357903 & E: kjb10@st-andrews.ac.uk \\
F: +61737355111 & \\
E: n.barter@griffith.edu.au & \\
\hline
\end{tabular}

\section{Abstract}

Over the past twenty years scholars have argued that key to achieving sustainability are the paradigms of organisational leaders, with their paradigms needing to move away from anthropocentric towards sustaincentric and or ecocentric perspectives. This paper reports on an empirical study that explored the views of leaders of a series of environmentally focused organisations, linking their views to the paradigm scheme of Gladwin, Kennelly, and Krause, (1995) in an attempt to understand how their rhetoric is aligned to different paradigms. Findings suggest that interviewees lean towards sustaincentrism and or ecocentrism in their rhetoric but that they also 
support some anthropocentric assumptions particularly with regard to economic assumptions. In support some simple practices brought forward by the sample as helpful in embedding sustainability awareness within their organisations are also highlighted. The paper concludes that the organisations suffer with fiscal drag but also demonstrate a new 'future normal.'

Keywords: paradigms, sustaincentrism, ecocentrism, anthropocentrism, technocentrism, future normal, fiscal drag

Biographical Notes on Authors

Dr Nick Barter

Nick's research focus is on strategy and sustainability. His particular focus is on conceptions held by organisations with an environmental/sustainable mission. The aim of Nick's work is to redefine strategy and its purpose.

Nick's work covers a range of areas and has included the use of Actor-Network Theory, the investigation of the ecoefficiencies required to achieve sustainable outcomes and the strategic responses of corporations to climate change. Current research areas include metaphors and the conceptions of the environment.
Prof. Jan Bebbington

Professor Jan Bebbington holds a Chair in Accounting and Sustainable Development in the School of Management at the University of St. Andrews and is also the Director of the St Andrews Sustainability Institute (also at the University of St Andrews) which was formed in 2006 to co-ordinate interdisciplinary research and to develop post-graduate degrees in sustainable development. Her research interests focus around the dual themes of corporate reporting on sustainable development and full cost accounting and modelling. Professor Bebbington was also Vice-Chair (Scotland) of the UK's Sustainable Development Commission 


\begin{tabular}{|l|l|}
\hline Outside of academia, examples of Nick's & from 2006-2011 and has an interest in \\
work include training a FTSE 100 & development within governments. \\
corporation's top 200 executives on & \\
including sustainable development as a & \\
value and judging environmental awards & \\
for NGOs and business organisations. & \\
Prior to working as an academic, Nick & \\
spent 13 years in industry in a range of & \\
strategic roles. & \\
\hline
\end{tabular}




\title{
Environmental Paradigms and Organisations with an Environmental Mission
}

\begin{abstract}
Over the past twenty years scholars have argued that key to achieving sustainability are the paradigms of organisational leaders, with their paradigms needing to move away from anthropocentric towards sustaincentric and or ecocentric perspectives. This paper reports on an empirical study that explored the views of leaders of a series of environmentally focused organisations, linking their views to the paradigm scheme of Gladwin, Kennelly, and Krause, (1995) in an attempt to understand how their rhetoric is aligned to different paradigms. Findings suggest that interviewees lean towards sustaincentrism and or ecocentrism in their rhetoric but that they also support some anthropocentric assumptions particularly with regard to economic assumptions. In support some simple practices brought forward by the sample as helpful in embedding sustainability awareness within their organisations are also highlighted. The paper concludes that the organisations suffer with fiscal drag but also demonstrate a new 'future normal.'
\end{abstract}

Keywords: paradigms, sustaincentrism, ecocentrism, anthropocentrism, technocentrism, future normal, fiscal drag 


\section{1- Introduction}

Environmental degradation has been widely discussed and documented by scholars (for example see: Daly, 1996; Ekins, 2000; Gray, Bebbington, and Walters, 1993; Hawken, Lovins, and Lovins, 2000; Lovelock, 2006) as well as agencies and institutions (for example see: The World Wildlife Fund (WWF) Living Planet report, 2006; The Intergovernmental Panel on Climate Change (IPCC) Fourth Assessment Report, 2007; the United Nations Millennium Ecosystem Assessment Report, 2005 and the Worldwatch Institute, 2004). The literature posits that environmental degradation has roots in society and its economic institutions, of which for-profit organisations are an important element.

Over the past twenty years, although not limited to this period, numerous management scholars (for example see: Colby, 1991; Devereaux Jennings and Zandbergen, 1995; Hanna, 1995; Hoffman and Sandelands, 2005; Shrivastava, 1995a) have argued that organisations and scholars alike are contributing to environmental and social degradation because, in the words of Gladwin, Kennelly, and Krause (1995), they are experiencing a "profound epistemological crisis" (ibid, p. 874). This crisis arises from the assumption that humans are separated from the rest of the natural world and this in turn impacts decisions and behaviour. In short, it is claimed that managers and management studies assumes the separation of humans and nature and is operating with an anthropocentric paradigm. The implications of this assumption is that if scholars and organisations are to contribute to ecologically and socially sustainable development they need to operate within a paradigm that does not treat humans and nature as separate, rather they need to adopt an environmental paradigm, a sustaincentric and or ecocentric paradigm. In turn this 
will help realise different decisions and behaviours that result in more ecologically and socially sustainable outcomes.

The management literature that considers how paradigms shape mindsets and actions with respect to the environment typically presents a continuum between, and inclusive of, the two poles of anthropocentrism ${ }^{\mathrm{ii}}$ and ecocentrism (for example see; Colby, 1991; Egri and Pinfield, 1999; Gladwin, Kennelly, and Krause, 1995; Hoffman and Sandelands, 2005; Purser, Park, and Montuori, 1995). Anthropocentrism views humans as the sole locus of value and separate from nature with nature only being of value as a resource to be utilised. Ecocentrism is found at the other end of the continuum and is "based on an ecologically informed philosophy of internal relatedness" (Eckersley, 2003, p. 49) centres on the need for maintaining the integrity of the ecology and views human needs in light of this assumption. Between these two poles, literature offers various hybrids that aim to incorporate aspects of the two positions and these 'middle way' paradigms are labelled, for example; reform environmentalism (Egri and Pinfield, 1999), environmental management (Purser, Park, and Montuori, 1995) or sustaincentrism (Gladwin, Kennelly, and Krause, 1995). iii Outlined in Table I below is the Gladwin, Kennelly, and Krause, (1995) paradigm scheme that is used in this study.

(INSERT Table I HERE)

As Table I indicates, paradigms most usually are represented as containing a number of assumptions that, taken together have coherence. There is, however, a relative lack of empirical research that explores how organisations' link to any paradigm and what assumptions are held by organisational leaders. A review of the research that examined views of individuals both inside and outside of organisations suggests that 
this work (for example see; Andersson and Bateman, 2000; Brych, et al., 2007; Dunlap and Van Liere, 2008; Egri and Herman, 2000; Kilbourne, Beckmann, and Thelen, 2002; Kilbourne and Carlson, 2008) has not focused on which particular assumptions (in relation to a paradigm scheme) are expressed. Rather research that discusses paradigms and paradigm adherence does so in general terms (Andersson and Bateman, 2000; Brych, et al., 2007; Egri and Herman, 2000; Halme, 1996). For example, Halme (1996) describes the paradigm views of two case study companies as "similar to" (Halme, 1996, p. 99) the frontier economics and resource management paradigms offered by Colby (1991) and discusses in general terms how this similarity evidences itself. Brych, et al., (2007) describe how the paradigm views of the individuals they interviewed "very generally" (ibid, p. 44) can be related to the Gladwin, Kennelly, and Krause, (1995) paradigm scheme. Further Andersson and Bateman (2000) highlight, in their study of environmental championing initiatives, that these initiatives are more successful in organisations where the environmental paradigm appears to be "strong" (ibid: p.564) - without specifying what makes up this environmental paradigm (it may be, as argued by Egri and Pinfield, 1999, that paradigms are not sufficiently detailed to be used in this way). Consequently, we would argue that existing research could be further developed by being more specific about which assumptions within a paradigm are supported.

This paper presents an exploratory study of how the views of leaders of a series of twenty three organisations that had what could be described as an 'environmental mission' as their core purpose relate to a paradigm scheme, specifically the Gladwin, Kennelly, and Krause, (1995) paradigm scheme. Thus the paper is presenting research conducted on organisations that are likely to have engaged in rethinking of the purpose of business and are likely to be adopting assumptions that are a move away from an anthropocentrism towards a sustaincentrism and or ecocentrism. In 
this regard, a result that indicates sustaincentric and ecocentric assumptions are supported may not be unexpected. However in contrast to the general adherence to paradigms discussed in previous studies (Andersson and Bateman, 2000; Brych, et al., 2007; Egri and Herman, 2000; Halme, 1996), this study attempts to understand how interviewees' rhetoric relates to specific assumptions within a paradigm scheme. Further in focusing on organisations with environment missions that are likely to already be grappling with the complexity of sustainability, an understanding can be gathered of how sustaincentric and or ecocentric organisations that could arguably be termed exemplars actually are. Furthermore given that an environmental paradigm is less likely to be evident compared to the mainstream anthropocentric paradigm; a deliberate bias to those less likely to support anthropocentrism was sought. The research's use of the Gladwin, Kennelly, and Krause, (1995) scheme was for two reasons. First, the scheme develops assumptions for each of the constituent paradigms (technocentrism, sustaincentrism and ecocentrism) and thus makes an exploration of various assumptions possible. Second, Gladwin, Kennelly, and Krause (1995) argue that depending upon which environmental paradigm is adopted there is a link to sustainable development. As through their paper they develop a case for how each paradigm does or does not support sustainable development through principles of inclusiveness, connectivity, equity, prudence and security.

The research was conducted between August 2007 and January 2008 and involved semi-structured interviews with 'leaders' of the organisations (for example, with founders, chief executives and managing directors). These interviews were transcribed and the text was coded using the paradigm framework of Gladwin, Kennelly, and Krause (1995) in order to attempt to understand how the views of the interviewees could be represented. 
The paper proceeds in the following manner. The next section discusses paradigms and the range of paradigms offered in the literature, with a focus on the Gladwin, et Kennelly, and Krause (1995) scheme. Next the research method and the research questions that helped the exploration of the views of the interviewees are outlined. The sample, data and process of analysis are then discussed prior to presenting the results of the analysis. The results are discussed and some simple practices are highlighted that the interviewees outline as helping the embedding of sustainability awareness within their organisations. Potential lines of future research and some summary statements on the views of the interviewees regarding fiscal drag and that they represent a new 'future normal' take us to the end of the paper.

\section{2 - Paradigms}

The term paradigm is associated with Kuhn's (1996) work on the nature of scientific change. Kuhn (1996) argues that a paradigm is closely related to the term normal science. Where "normal science means research firmly based upon one or more past scientific achievements that some particular scientific community acknowledges for a time as supplying the foundation for its further practice" (Kuhn, 1996, p. 10). Within social science, Burrell and Morgan's (1979) classic text highlights that the term paradigm is "intended to emphasise the commonality of perspective which binds the work of a group of theorists together in such a way that they can be usefully regarded as approaching social theory within the bounds of the same problematic" (ibid, 1979, p. 23). Milbrath (1984) defines a paradigm as "...the values, metaphysical beliefs, institutions, habits, etc [t]hat collectively provide social lenses through which individuals and groups interpret their social world" (ibid, p. 7). 
More widely, when describing paradigms management scholars have used a range of descriptors such as; world view, meta narrative, core beliefs, shared values and shared assumptions held by a particular group of actors (for example see; Colby, 1991; Cummings, 2005; Egri and Pinfield, 1999; Gopalkrishnan, 1999; Shrivastava, 1995a). What the definition and descriptors indicate is that a paradigm describes individual or group views of the nature of the world. Further it should be noted that a paradigm or its constituent assumptions is not necessarily a proven state of affairs, rather it can be an aspiration which nevertheless has consequences in terms of behaviour (for example see; Brych, et al., 2007; Johnson, 1996; Morgan, 2006; Schien, 1992; Scott, 1995). iv Thus paradigms proposed as supporting sustainable outcomes such as sustaincentrism and ecocentrism could be argued as dealing in aspiration and investigating whether they are supported and in particular which assumptions within them are evidenced is particularly relevant to formulation of new understandings in the field of management (for example see; Colby, 1991; Devereaux Jennings and Zandbergen, 1995; Egri and Pinfield, 1999; Hanna, 1995; Pauchant, 1996; Purser and Montuori, 1996).

The understanding of a paradigm has also been discussed in the context of the 'dominant social paradigm' (DSP). The DSP has been defined as a "world view through which individuals or, collectively, a society interpret the meaning of the external world...[and]... a mental image of social reality that guides expectations in a society" (Dunlap and Van Liere, 2008, p. 19 citing Pirages and Ehrlich, 1974, p. 4344); or as "the values, metaphysical beliefs, institutions, habits, etc, [t] hat collectively provide social lenses through which individuals and groups interpret their social world" (Milbrath, 1984, p.7). These definitions of paradigms highlight that they consist of assumptions of ontology, ethics and values held by a particular group of actors and that these collections of views have an impact on practice/behaviours. 
The management literature that discusses environmental paradigms typically builds from a base that the DSP and or traditional management paradigm is anthropocentric. That is, there is a "belief that there is a clear and morally relevant dividing line between humankind and the rest of nature, that humankind is the only or principal source of value and meaning in the world, and that nonhuman nature is there for no other purpose but to serve mankind" (Eckersley, 2003, p.51). In turn, this belief leads to individuals and organisations seeing their wider environment as something they are not connected to, a separate other. Moreover, if one sees humans as the sole locus of value the environment becomes objectified, thereby leading to its degradation (for example see; Gladwin, Kennelly, and Krause, 1995; Gopalkrishnan, 1999; Hoffman and Sandelands, 2005; Pauchant, 1996; Shrivastava, 1995a). Consequently, the argument is made that individuals and organisations need to embrace an environmental paradigm that dissolves the dividing line between humans and nature, thus providing the environment with inherent value. This may also allow organisations to more readily contribute to ecologically and socially sustainable development (for example see; Egri and Pinfield, 1999; Hanna, 1995; Halme, 1996; Hoffman and Sandelands, 2005; Starik and Rands, 1995).

Within the literature, paradigm schemes are typically offered as a range of paradigms as either, a dichotomy between two poles of anthropocentric and ecocentric paradigms ${ }^{\vee}$ (for example see: Gopalkrishnan, 1999; Shrivastava, 1995a) or as a continuum between and inclusive of the poles of anthropocentrism and ecocentrism, where the poles are extremes and paradigms in between are variously labelled: reform environmentalism (Egri and Pinfield, 1999), environmental management (Purser, Park, and Montuouri, 1995) or sustaincentrism (Gladwin, Kennelly, and Krause, 1995). 
The different schemes also describe assumptions concerning; organisational goals, economics, views of technology, system structure, the environment, consumerism, knowledge and an overarching metaphor (for an example see Table I). To characterise the paradigms: the assumptions within anthropocentrism are unlimited economic growth, a belief in neoclassical economics and the free market, technological optimism, hierarchal structures, the environment being a resource to be utilised according to human needs, ${ }^{\text {vi }}$ consumerism should be unrestricted, knowledge is rational, reductionist and based on dualisms and the overarching metaphor for the environment is that it operates as a machine (Devereaux Jennings and Zandbergen, 1995; Egri and Pinfield, 1999; Hoffman and Sandelands, 2005; Purser, Park, and Montuori, 1995; Shrivastava, 1995a).

Conversely ecocentrism has assumptions of: holistic balance and ecological integrity, steady state economics, technological pessimism, non hierarchal participative decision making, humans are a member of the environment, the environment has moral, aesthetic and symbolic value rather than purely utilitarian value, post consumerism, knowledge being based on holistic, integrative and dialectic views and the overarching metaphor is organism (Devereaux Jennings and Zandbergen, 1995; Egri and Pinfield, 1999; Gladwin, Kennelly, and Krause, 1995; Purser, Park, and Montuori, 1995; Shrivastava, 1995a).

Paradigms in between these two poles, offer various gradations or hybridisations of the assumptions found under anthropocentrism and ecocentrism. To illustrate, these paradigms tend to have assumptions of: the goal being sustainable development, quality of life and reduction of inequities, an economic framework that incorporates natural capital principles, a cautious treatment of technology, decision making that is 
hierarchical yet collaborative, humans are the stewards of the environment, green consumerism is pursued, knowledge is balanced between reductionism and holism and an overarching metaphor of machine/system or life support system (Egri and Pinfield, 1999; Gladwin, Kennelly, and Krause, 1995).

A defining thread running through the paradigm schemes is the way self-interest is conceptualised. At the anthropocentric end of the continuum, self interest does not extend beyond the short term survival of the individual. In contrast, at the ecocentric end of the continuum self interest includes all forms of life and in between it encompasses various gradations of progeny, the human species and elements of the wider collective (Egri and Pinfield, 1999).

One of the difficulties with the paradigm schemes, aside from attempts to condense them into a limited set of assumptions, is that they are in effect 'straw men' (Egri and Pinfield, 1999). For example, the assumption within anthropocentrism is a belief in the continual pursuit of free market principles. However as Egri and Pinfield (1999) highlight that "rational free market principles are continuously compromised and adjusted to accommodate subjective irrationality" (ibid, p. 217). Likewise when considering ecocentrism, its "utopian, abstract, radical nature" (Egri and Pinfield, 1999, p.219) indicates that it is unlikely to be accepted by society or managers in organisations because it challenges "not only the field of strategic management...but most of Western philosophical and religious traditions" (Hanna, 1995, p. 797 citing Pauchant and Fortier, 1990). Thus it can be argued that neither anthropocentrism nor ecocentrism in their purest form are likely to ever come to pass. Given this, it is perhaps unlikely that any individual(s) will adhere to either anthropocentrism or ecocentrism and thus the offering of a middle way paradigm such as sustaincentrism (Gladwin, Kennelly, and Krause, 1995) could be viewed as pragmatic. Albeit the 
pragmatism has a robust base in that it does recognise the role of human intellect relative to other biota and do not attempt to neither make us the sole subject (anthropocentrism) nor reduce us to a hapless object (ecocentrism) (Gladwin, Kennelly, and Krause, 1995; Hoffman and Sandelands, 2005). However the pragmatism does render middle way paradigms subject to potential intellectual perforation because they are, via their hybridisation, ambiguous, incoherent and attempting to incorporate a paradox of environmental sustainability and continued economic growth on a limited planet (Banerjee, 2003; Egri and Pinfield, 1999; Gopalkrishnan, 1999; Purser, Park, and Montuori, 1995), claims anthropocentrism and ecocentrism do not have to tolerate because of their extreme positioning. In this regard middle way paradigms can be seen as not being radical enough given the challenges facing humanity and they could be seen to perpetuate a view that "we can continue to have our economic cake and eat it, too, without undergoing fundamental changes in lifestyle or thinking (Purser and Montuouri, 1996, p.612).

Nevertheless, middle way paradigms do find support in the literature for being optimistic and pragmatic (Brych, et al., 2007; Hoffman and Sandelands, 2005; Johnson, 1996). Further, if one believes that change comes about incrementally by taking people with you, these paradigms are more likely to be acceptable to decision makers and wider society as opposed to being written off as "irrelevant rhetoric" (Hanna, 1995, p. 798). Thus through incremental shifts, middle way paradigms are potentially a "portal into ecological awareness" (Johnson, 1996, p. 609) - a potentially desirable end in the pursuit of sustainability.

In summary, although paradigms may face difficulties in their attempts to reduce a complex world into a finite number of assumptions, it would appear that they do provide an opportunity to interrogate the implicit assumptions behind the rhetoric of 
organisational actors. This research uses them in an attempt to understand how a particular set of actors adhere (or not) to a paradigm scheme and thus seeks to provide insight into paradigms and their particular assumptions.

\section{3 - Research Method}

Studies exploring paradigms have employed a variety of methods from the use of questionnaires (for example; see Dunlap and Van Liere, 2008; Kilbourne, Beckmann, and Thelen, 2002; Shafer, 2006), semi-structured interviews (for example see; Halme, 1996; Brych, et al., 2007) or a mix of the two (for example see; Andersson and Bateman, 2000; Egri and Herman, 2000). All of these methods highlight that paradigms are reflected in discourse. This study used semi-structured interviews to gather data. This enabled interviewees' points of view to be elicited, discussed and questioned to clarify understanding. Questioning and clarifying is not readily available via a survey method and yet it is a technique that is particularly useful given the generality inherent in paradigm schemes. This aspect coupled to the exploratory nature of the study resulted in the consideration that semi-structured interviews provided the most appropriate method because of its inherent flexibility. vii

During the interviews, the interviewees were not presented with the paradigm scheme of Gladwin, Kennelly, and Krause, (1995) (see Table I). Rather, five questions were developed, questions that would allow an elicitation of interviewees' views per se, as well as paradigm adherence to be explored, thus allowing the research, to a degree, to manage risk. These questions drew upon: perceptions of the boundaries of organisations, notions of sufficiency or enough in terms of return 
from business activities, the pursuit of profit maximisation, the desirability of quoted status and the role of money as a means or as an end.

Taking each question in turn, the question of how the boundary between the organisation and the environment is understood provides data on the key distinction made between competing paradigms regarding the extent to which humans are separate from the natural world. Within an organisational context, Purser, Park, and Montuori, (1995) argue that if an anthropocentric view is taken, an organisation will view itself as "standing outside" (ibid, p. 1064) of the environment. Conversely organisations that subscribe to an environmental paradigm are likely to view the organisation as having "systemic interconnections" (Shrivastava, 1995b, p. 942) and thus a boundary is either not or less perceptible.

The notion of sufficiency was explored because anthropocentrism is criticised due to one of its assumptions being that growth can continue ad infinitum and, in turn, that all organisations can grow indefinitely. This sort of assumption is reinforced, for example, by classic conceptions of strategy which are predicated on growth, particularly growth in monetary wealth (for example see: Collison, 2003; Devereaux Jennings and Zandbergen, 1995; Egri and Pinfield, 1999; Shrivastava, 1995a; Whittington, 1993). Conversely, ecocentrism recognises that there will be limits to growth because of the biophysical constraints of the earth (for example see; Colby, 1991; Devereaux Jennings and Zandbergen, 1995; Gladwin, Kennelly, and Krause, 1995; Jackson, 2009, Meadows, Randers, and Meadows, 2005). Given this, an organisation pursuing an environmental paradigm is likely to be able to demonstrate some examples of where they intentionally pursue sufficiency. viii 
Building upon the exploration of sufficiency, the third question explored interviewees' views on profit maximisation. Profit maximisation and its pursuit are taken as being axiomatic of conventional management narratives and the anthropocentric paradigm (for example see: Collison, 2003; Devereaux Jennings and Zandbergen, 1995; Egri and Pinfield, 1999; Gladwin, Kennelly, and Krause, 1995). When considering sustainability, the difficulty of profit maximisation is that, if pursued, it will result in an organisation externalising as many costs as possible and thus exacerbating environmental degradation. As a result, profit maximisation is not a constituent assumption of an environmental paradigm.

The fourth question builds upon the question of pursuit of profits and explores whether the organisations favour or reject becoming quoted on a stock exchange. Smith (2003) argues quoted organisations have to focus on "perpetual growth in profitability" (Smith, 2003, p. 366) and "all life in the corporate world [becomes] a function of the money that is being made or not made" (ibid, p. 358). Thus quoted organisations arguably have a sole locus of value that is money and will engage in behaviour that is counter to assumptions within environmental paradigms (Egri and Pinfield, 1999; Gladwin, Kennelly, and Krause, 1995). As a result, one would expect that listed status would not be sought or seen to be desirable if interviewees are adopting an environmental paradigm.

The fifth question aims to explore the role of money and understand whether it is a locus of value or whether the organisations are pursuing wider objectives such as quality of life. Indeed, it is an assumption of environmental paradigms that money is not viewed as an end in itself. Rather, it is a means to an end. 
Taking these five questions together and some additional questions regarding timeframes adopted for decision making (short (anthropocentric) or long (ecocentric)) and whether the environment was seen as being primary relative to the organisation (ecocentric) or vice versa (anthropocentric) interviews were conducted.

Given the exploratory nature of the study, in order to elicit a representative view or an organisation, the leaders of organisations were targeted for interview. A focus on leaders is important as one of the fundamental tasks facing leaders is creating "shared meaning" (Morgan, 2006, p. 147) and an organisation can be viewed as the "epitome of the purposes of its designer, its leaders or key members" (Katz and Kahn, 1966, p. 15). Further it is the "decision makers [that] typically determine a firm's strategy [and] the dispositions, cognitions and motivations of these individuals can influence firm-level outcomes" (Kilduff, Anger, and Staw, 2010, p. 946). Thus the assumptions and views of organisational leaders are used to determine the paradigms' of organisations and their subsequent behaviour (for example see: Bansal and Roth, 2000; King and Lenox, 2002; Meima, 1994; Plaza-Ubeda, et al., 2007; Sethi, 1995).

As outlined earlier the individuals targeted for interview were the leaders of organisations that had their "commitments to nature clearly articulated in mission statements" (Shrivastava, 1995a, p. 131). This was the key selection criteria for whether an organisation should be approached, as opposed to industry or country (notwithstanding the limitations of the researcher's language capabilities). This focus was taken as organisations with these types of missions were viewed as most likely to be able to offer views that indicate which assumptions across the paradigm scheme are being adhered to. In so doing an understanding of how sustaincentric and or ecocentric organisations that could typically be termed exemplars actually are 
could be gained. Further given that an environmental paradigm is less likely to be evident compared to the mainstream anthropocentric paradigm; a deliberate bias to those less likely to support anthropocentrism was sought. Organisations to interview were determined through a mix of referrals, media articles, academic readings and internet searches and 31 organisations were approached for interview with 23 agreeing to be interviewed. Of the 23 that agreed to be interviewed three were based in the United States of America (seventh GENERATION, Recycline, TerraCycle), one in Belgium (Ecover) and the remaining 19 were based in the United Kingdom. Examples of the mission statements of the organisations targeted for interview were as follows:

- 'Triodos Bank finances companies, institutions and projects that add cultural value and benefit people and the environment, with the support of depositors and investors who want to encourage corporate social responsibility and a sustainable society. Our mission is;

- To help create a society that promotes people's quality of life and that has human dignity at its core.

- To enable individuals, institutions and businesses to use money more consciously in ways that benefit people and the environment, and promote sustainable development.

- To offer our customers sustainable financial products and high quality service.' (Triodos Bank, www.triodos.co.uk)

- 'The Green Stationery Company is the UK's premier recycled paper and green office products supplier. We select products are environmentally benign or have environmental advantages over the standard office products. We aim to maintain business practices consistent with the goals of sustaining our fragile environment for future generations, within a culture that respects life and honours its interdependence.' (The Green Stationery Company, www.greenstat.co.uk) 


\section{4 - Sample \& Process of Analysis}

The 23 organisations that agreed to an interview ranged from seventh GENERATION (a cleaning products company) to Triodos Bank (a provider of banking services to consumers and business). An overview of the organisations and their trading names, where permissions allow, is provided in Table II.

(INSERT Table II HERE)

These organisations represent a range of ownership structures with seventeen of them being privately owned organisations, three being owned or partially owned by quoted organisations, one being a mutual, one a co-operative and one a charity. With regard to number of staff in the organisations, at the time of the interviews, six had less than ten employees, eleven had between 11 and 50 employees, three between 51 and 100 employees and three had between 101 and 200 employees. As highlighted in Table III, 25 individuals from the 23 organisations were interviewed (with two individuals being present in two interviews).

(INSERT Table III HERE)

As can be seen the interviewees tended to be founders. However this category is derived. This is because all of the founders interviewed were in operational control of their organisations and used titles such as chief executive officer (CEO) or managing director, to distinguish these individuals who had founded the organisations from those who were employed by an organisation but also had a title 
of CEO or alike a separate category of founder was formulated and indicated (as shown in Table III above). Outside of the more easily recognisable titles in Table III that denote leadership, the title of 'member' was used for the individual interviewed from the co-operative who was the spokesperson for the organisation. However, because formal titles were not used in the organisation it was agreed that a title of member would be appropriate.

The interviews lasted between 45 minutes and two hours and, with the exception of one, were recorded and transcribed. Of the interviews fifteen were face to face and eight were via the telephone. Of these telephone interviews three were conducted with individuals based in the USA and one with an individual based in Belgium. ${ }^{\text {ix }}$ The remaining four telephone interviews were conducted via this media to facilitate diary constraints either on the part of the researcher or the interviewee. During the interviews the research questions were used as an aid memoir throughout the interviews but their exact wording or order was not strictly adhered to (as per semistructured interview practice).

After the interviews had been transcribed the interviewees' comments were analysed relative to the paradigm scheme offered by Gladwin, Kennelly, and Krause, (1995) (see Table I). This analysis involved inputting the scheme's 90 assumptions (30 assumptions per paradigm of technocentrism, sustaincentrism and ecocentrism) into the NVivo software coding tool and then reviewing the transcripts and assigning text that provided evidence of agreement with particular assumptions. Through this analysis, 168 pieces of text from the transcripts were coded to 18 of the 90 assumptions. One of the key difficulties with the process of coding transcript text to the scheme was that that the assumptions from Gladwin, Kennelly, and Krause, (1995) lack clear definitions. This is perhaps to be expected given the 'strawman' 
aspect of paradigms (Egri and Pinfield, 1999) and Gladwin, Kennelly, and Krause's (1995) highlighting that their paradigm scheme has no hard boundaries between each paradigm and the paradigms are not "closed or monolithic" (ibid:881). Rather their scheme should be should be viewed as being "heuristically useful" (ibid, p. 881) and offering "coherent persuasiveness" (ibid, p. 882) as opposed to a closely framed guide with distinct Cartesian categories.

\section{5 - Results}

The Gladwin, Kennelly, and Krause, (1995) paradigm scheme (Table I) contains three paradigms each with 30 assumptions. The 30 assumptions are split into three groups of ten under the titles of 'ontological \& ethical,' 'scientific \& technological' and 'economic \& psychological' assumptions. Analysing the interviewees' commentary and coding pertinent text to the paradigm scheme offered by Gladwin, Kennelly, and Krause, (1995) resulted in elements within the 'ontological \& ethical' and the 'economic \& psychological' groupings having text coded to them. Consequently the results are considered under each of these categories and following these two categories there is some very brief discussion and Table VI is offered to highlight some of the simple practices that the interviewees' offered as being supportive of embedding an appreciation of environmental and social sustainability into organisational participants. Lastly it should be noted that no text was identified that was relevant to be coded to 'scientific \& technological' assumptions. This is not an unexpected result given the focus of the interview questions that is they focused on the fundamental underpinnings regarding organisations and their operations rather than on a consideration of the immediacy of an environmental issue. Further given these issues did not emerge it could be assumed, especially given the stated claims 
of the organisations, that this range of issues could be taken as accepted and did not require reiteration. ${ }^{x}$

\section{Economic \& Psychological Assumptions}

Table IV highlights how the interviewees' views map to the economic \& psychological assumptions of the Gladwin, Kennelly, and Krause, (1995) scheme. The shading indicates which assumptions were reflected in the interviewees' commentary with the numbers indicating how many interviews had text that was cognate with the assumption. The table indicates that the interviewees could be described as being sustaincentric in orientation, with an orientation towards technocentrism in the area of economic structure, the role of growth and political structure. Two interviewees leaned towards ecocentrism in the area of political structure. The table also highlights how no interviewees commented on assumptions concerning human nature, poverty alleviation, natural capital and discount rate. This might not be unexpected given the interview questions did not specifically explore these issues, but equally given they did not emerge; one might assume that these are not in the forefront of interviewees' minds.

(INSERT Table IV HERE)

As Table IV highlights, ${ }^{\text {xi }}$ interviewees most frequently cited the primary objective of their organisation as being concerned with quality of life and a balance of social, environmental and economic outcomes. One interviewee, for example, noted that their focus is on "how can we design every moment for one hundred percent of the wellbeing of all humanity?" (seventh GENERATION, Director of Corporate Consciousness). Further if environmental and social outcomes and more broadly 
quality of life, outcomes are not being met then "there's no point [in having] a business in the first place" (People Tree, General Manager), as the purpose is not to maximise returns but to take a more "sustainable view" (Triodos Bank, Managing Director). Further money is viewed as allowing the "flexibility of being able to carry on putting things back" (revolve, founder), rather than being a positive outcome in and of itself. A point made particularly clear by two interviewees, one who commented that their perception was that the founder "puts the environment first and finance second and I would say our new financial director puts finance first and the environment second" (Terra Plana, interviewee) while the other commented that "I've heard somebody in finance say oh why don't we cut retail off and just focus on wind farms cos they make more money. Do you know, I say 'Well, you know, that's not what we're here for, so forget it" (Company B, founder).

The objectives of the organisations are elucidated in a variety of ways, including that their aim is to facilitate customers making "ethically responsible choices in what they do buy" (By Nature, founder) rather than just buying more (a view that could be seen to be representative of a post materialism viewpoint). For the interviewees, offering an ethically responsible choice to the market arises from their assumption that wider societal and industrial change can be achieved though this approach (an aspect explored further below).

With regard to economic structure, Gladwin, Kennelly, and Krause, (1995) characterise the green economy as one that internalises ecological and social externalities while still operating within some degree of 'freedom'. Interviewees' views are not fully located within one paradigm for this assumption. Rather their views compose a more technocentric point of view as well as reflecting some desire to move beyond a narrow form of technocentrism. The interviewees discussed how 
they aim to provide products and services that are "an improvement on the standard stuff" (Green Stationery Company, founder) and thus they are internalising costs. This is possible because (and linked back to objectives), for them, "the absolute maximum profit isn't what counts and nor is the timeframe" (Company B, founder). Further, they aim to use "trade not just to make money but to derive money and to push that towards the environment" (belu, founder). However, the interviewees also take a view that they cannot be completely idealistic in their pursuit of environmental outcomes as if something "fantastically ecological or sustainable cannot be done in a rentable way" (Ecover, Concept Manager) then it cannot be done (at least at the present point in time). Thus, while the interviewees are committed to reforming markets and showing that "we can be far more adventurous with organisations and helping the planet" (belu, founder) and pushing towards the "next area of social and environmental change" (Triodos Bank, managing director). At the same time, they are clear that unless they are viewed as being financially successful, at some level, then they will achieve little as "nobody copies failure" (howies, cofounder).

This mixing in paradigm assumptions is also reflected in the interviewees' comments regarding growth and their view on how their organisations can facilitate change. The interviewees were clear that their organisations' growth is desirable, because it is switching people's consumption to more benign solutions and thus when they sell more, "more good" (Recycline, operations director) is achieved. Further they argued that once a customer had bought a product this may create the chance for further change if the customer has their values challenged. One interviewee hoped that having engaged with them, customers may start to ask "why do these guys do this?" (Ecover, Concept Manager). The interviewees also took the view that if their organisations grow this helps to demonstrate to others that their offering is "credible 
and that might encourage others to move" (Triodos Bank, Managing Director). Thus a belief in growth being good and necessary (a technocentric assumption) is present. However, the interviewees also demonstrate that they are conscious that growth might result in an issue whereby their success could result in an increased environmental burden, where their organisations' "become more of a problem" (howies, co-founder). Another concern that was expressed about growth for the individual organisations, focused around the impact growth and the resultant larger organisation, would have upon organisational culture. The interviewees were clear that they did not want to turn their organisations into, for example, a large bureaucratic "dinosaur" (seventh GENERATION, Director of Corporate Consciousness). Rather, the desire was to maintain informality and retain "integrity" (Triodos Bank, managing director) and this was thought to be related to absolute size. Thus the interviewees display some paradoxical views about growth. Growth is viewed as both good but also mixed and thus their views share allegiances with both the sustaincentric as well as technocentric paradigm.

Turning to the question of trade, a small number of the interviewees highlighted that their preference was for national trade patterns and that product should not be shipped in from overseas if a local alternative was available. With regard to political structure, the interviewees placed an emphasis on maintaining flat structures within their organisation and ensuring that individuals "feel part" (TerraCycle, co-founder) of the organisation through town hall type meetings and other activities (for example, BioRegional have lunch clubs where every employee works to a rota of preparing lunch for the whole team). However, interviewees also outlined that they operate with conventional (hierarchal) organisational structures and that while they aim to devolve decision making sometimes the interviewees (as leaders of their organisations) "end up having final decisions about things, because someone has to 
at the end of the day" (Green Stationery Company, founder). Thus the interviewees offered views where their organisations are centralised yet there was also an aspect of reluctant leadership as "people do expect you to be leading them a bit" (BioRegional, co-founder). Further, they also appeared to recognise that "old fashioned hierarchy" (Ecover, concept manager) blocks development as it does not foster consultation and dialogue. Thus the interviewees reflected aspects of both centralisation and devolution orientations. The outliers on the political structure assumption were seventh GENERATION and Company D, who expressed that they would like to break up their organisations into small local units with no central oversight.

\section{Ontological \& Ethical Assumptions}

Table $\mathrm{V}$ highlights the pattern of coding in the area of ontological \& ethical assumptions. This table suggests that the interviewees were sustaincentric with some interviewees leaning towards ecocentrism and a few towards anthropocentrism on particular assumptions.

(INSERT Table $V$ HERE)

Overall the table suggests that with respect to the relationship between humans and nature, interviewees were predominantly sustaincentric in orientation. This arises because the interviewees were clear that they saw themselves as stewards of the earth, of having a "duty of care" (Green Building Store, founder) towards nature and working to understand how their organisation could "fit into the ecosystem" (Pillars of Hercules, founder). Two of the interviewees (Company E and Green Building 
Store) went further and offered views which demonstrate a mixing of ecocentric and sustaincentric views, seeing themselves as being indistinguishable from nature (indisassocation in Gladwin Kennelly, and Krause, (1995) terms). For example they took a view that operating in an environmental sustainable manner was part of their "DNA rather than just bolted on" (Green Building Store, founder) and that humans are part of the "chain" of being (Company, E, founder).

As is also apparent from Table $V$, interviewees also expressed views about the timeframes in which decisions were made with interviewees typically operating on a three to five year planning cycle, albeit that cycle was guided by "generational issues" (Green Stationery Company, founder). During the Ecover interview indefinite timescales were identified, in terms of their work would never be finished. In contrast, Company A asserted that their focus was short term. The text coded to the system structure assumption reflects comments from two interviewees regarding a requirement for whole systems thinking coupled to the integrity of the individual and their actions within this context.

It is also apparent from Table $\mathrm{V}$ that no text was coded to assumptions concerning a metaphor of earth, perception of earth, system composition, value of nature, ethical grounding or logic/reason. This is not unexpected given these specific points were not explored. However, it is worth noting that positions on these matters could be deduced from aspects of the interviews. Caution with the data, however, has prevented us moving in this direction. For example, the founder of Company $E$ described himself as being "umbilically attached" to nature. By extension it could be assumed that this interviewee's metaphor for the earth might be that of mother/web of life (an ecocentric assumption). However, given that the conversation did not explicitly touch on metaphors of the earth, this leap has not been made in this paper. 


\section{Simple Practices}

While the views of the organisational leaders' can be mapped to the paradigm scheme of Gladwin, Kennelly, and Krause, (1995) as discussed. The interviewees were also asked to elucidate on how their organisations reinforce everyday practices that are congruent with its mission. To this end, the interviewees offer some simple examples of practices they engage in. These examples are listed below in Table VI and although they could be viewed as simple and perhaps the application of simple common sense, they do offer a further understanding to the reader of the general modus operandi of the organisations interviewed and how environmental and social sustainability awareness can be embedded without overt complexity.

(INSERT Table VI HERE)

\section{6 - Discussion and Future Work}

Although the data set is limited to the leaders of environmentally focused organisations what this study has highlighted are the paradigms that the interviewees' draw upon when discussing their organisations and that their views have resonance with a sustaincentric perspective, as outlined in Gladwin, Kennelly, and Krause, (1995). While this result is perhaps unremarkable, given the research subjects, it should be noted that only a few management studies have been identified that attempt to operationalise environmental paradigms (Andersson and Bateman, 2000; Brych, et al., 2007; Egri and Herman, 2000; Halme, 1996) and only one (Brych, et al., 2007) has been identified that attempts to operationalise the 
Gladwin, Kennelly, and Krause, (1995) scheme. Yet as discussed earlier numerous papers have been written that call for the embrace of environmental paradigms (for example see: Brych, et al., 2007; Hoffman and Sandelands, 2005; Kilbourne, Beckmann, and Thelen, 2002; Purser and Montuori, 1996; Starik and Rands, 1995).

In this regard the study is supportive of the findings of other studies that have found evidence of environmental paradigms being adopted (Andersson and Bateman, 2000; Brych, et al., 2007; Egri and Herman, 2000; Halme, 1996) by organisational participants and adds to this body of literature. In particular it adds to the one other work by Brych, et al., (2007) that has been identified as attempting to operationalise the Gladwin, Kennelly, and Krause, (1995) scheme. Aside from this, a unique contribution of this paper and where it differs from others is that it has drawn out how interviewees' views relate to specific assumptions. In this regard it has shown how interviewees' views are not only reflective of sustaincentrism but also contain elements of both ecocentrism and technocentrism as well, depending upon the particular issue being considered. Furthermore this research highlights the views of organisational leaders from those organisations which could be considered as exemplars given their organisations' environmental/sustainability focus. Thus in this regard there is a reflection point with regard to how sustaincentric or ecocentric can any organisation be in its views and against which assumptions, at a particular point in time. That the views of the interviewees lack one to one mapping to a particular paradigm and or its constituent assumptions is not surprising, given that Gladwin, Kennelly, and Krause, (1995) are clear that their scheme is "not photorealistic" (ibid, p.881) nor are the paradigms "closed or monolithic" (ibid, p. 881), thus the paradigms of techno, sustain and ecocentrism are not Cartesian categories. Nevertheless the attempt to map views on particular assumptions remains valid and 
sheds light on the rhetoric of these interviewees, further it outlines areas for potential focus and future research as discussed below.

In particular, it is apparent that the interviewees view humans as having a stewardship role and a relationship of interdependence with nature. This suggests that the leaders of these organisations are not taking a view that the environment is something separate to them or something to be exploited. Rather, the environment is something that they have to be integrated with and that their organisations have a purpose that can only be realised within environmental constraints. This implies that organisations can do more than take the environment into account only when 'winwin' opportunities present themselves. It also suggests that organisational survival does not require that the environment be exploited.

What is apparent from the pattern of coding in the economic \& psychological assumptions is that the interviewees are caught between sustaincentric assumptions, while also demonstrating aspects of adherence (via growth commitments) to technocentrism. In short they are caught between their sustaincentric views and having to operate in the economy as is (technocentrism) and thus they are "using the tools of business to solve social and environmental problems... [and] trade not just to make money but to derive money and to push that towards the environment" (belu, founder). This result is not to be unexpected if the argument of Kuhn (1996) is accepted that paradigm assumptions continue to be subscribed to as long as they have some validity. Taking this point further, what is apparent is that the organisations view of their purpose to be more than money making. Rather, they want their organisations to facilitate change to both customers and competitors towards more environmentally sound outcomes. With respect to customers, interviewees hope their products encourage customers to be more environmentally 
aware. A desire to change competitors and industry was expressed by interviewees and that their organisations could exist and flourish was seen as a way to show leadership to peers. In wanting to change customers' perceptions it could be argued that the interviewees' view their organisations as agents for enabling paradigm change (although this assumption is questioned in other literatures, see Crompton, 2008; Crompton and Thorgersen, 2009).

The key message from these interviews is that organisations can be sutaincentric and or ecocentric in their views and through this conventional views of organisational purpose where profit maximisation is a sole goal (for example see: Andersson and Bateman, 2000; Devereaux Jennings and Zandbergen, 1995; Egri and Pinfield, 1999; Shrivastava, 1995a; Whittington, 1993) can be challenged. Thus with regard to ontological and ethical assumptions these individuals are already moving towards more sustainable perspectives and supportive of the general call regarding the adoption of environmental paradigms. However, what the work also highlights is that the interviews have economic \& psychological assumptions that reflect both sustaincentric and technocentric paradigms. In this regard, the views of the leaders are tempered by having their organisations operate and be viable within an economic system that is, rather than how they would perhaps like it to be. A point made clear through the following interviewee quotes; if something "fantastically ecological or sustainable cannot be done in a rentable way" (Ecover, Concept Manager) then it cannot be done or as seventh GENERATION outlined "[we] couldn't sell social justice as a product ${ }^{\mathrm{xii}}$ and so [had] used the environment as a way of reaching towards social justice" (seventh GENERATION, Director of Corporate Consciousness).

This leaning towards ecocentrism from sustaincentrism within 'ontological \& ethical' assumptions and the lean the other way, towards technocentrism from 
sustaincentrism in the 'economic \& psychological' is captured within Figure 1 below which captures the patterns of coding from Table IV and Table $V$ into one schematic.

\section{(INSERT Figure 1 HERE)}

We suggest that this result points towards the interviewed organisations suffering 'fiscal drag'. That is, while they are able to innovate and pursue strategies of differentiation that allows them to be viable, they still have to operate in the economy as is. At the same time, however, they are not unselfconsciously accommodating. The ontological positions they are taking point towards the possibility that they are challenging conventional business notions (the fractured epistemology in Gladwin, Kennelly, and Krause's 1995, terms) and embracing as Jonas (1984) highlights, a role of stewardship. Whereby the responsibility humans have regarding the planet cannot be abjured, in this context the interviewees' organisations could be summed up as having an eye on the future normaliii, as in their own words, they note:

[...talking about sustainability and the organisation] "Sometimes when I talk to people I realise that for us what's normal is not normal for everybody else. I just realise how far we've come and how much we know. But I just do think that it isn't weird and it is just, we're just slightly in the future" (BioRegional, co-founder)

"now people say that's green and, and ethical, and I'm like oh well I'm not sure it's either, but I think it should be normal behaviour to try and run your business in as good a way as possible. So, you know, it's not normal to be a polluter or, or at least it shouldn't be. So that's why I'm slightly nervous about all this stereotyping, and you know you're green in your articles, that kind of makes it sound like that's odd 
behaviour and what I'm trying to achieve is to make that normal" (howies, cofounder)

While the rhetoric supports this summary, what is also apparent is that their rhetoric, aside from the statements inherent in their organisations' offerings and the associated messaging and packaging, is supported by some remarkably simple practices as evidenced in Table VI, to help embed sustainability awareness within organisational members. In this regard that the organisations are trading and adopting simple practices, does point to a position that the embrace of sustainability does not need to be circumscribed with complexity in practices.

In summary, this study has suggested that paradigm schemes are heuristically useful. The extent to which interviewees views can be interpreted as related to a particular paradigm or to particular assumptions within a scheme allows us to use the likes of Gladwin Kennelly, and Krause's (1995) work in a more analytical manner than it previously has been. Further, the scheme itself allows tensions that an organisation faces to be elucidated and in so doing potentially investigated further. However this work is only exploratory in that it only investigated a limited data set and it applied a paradigm scheme to views, albeit the questions were informed by paradigm discussion papers. In this regard the study was cautious, consequently in future studies it would be advisable to perhaps avoid the caution and investigate environmental paradigm adherence as a sole focus, whereby all the assumptions within a paradigm scheme are investigated and probed. Further future research might involve conducting a longitudinal study with both leaders of the organisations and multiple layers of organisational participants to add to the robustness of the findings regarding paradigm adherence as well as allowing further understanding of how rhetoric is translated into reality. Likewise given the results it would be 
worthwhile testing the views of individuals from non-environmentally focused organisations, as a caution over the findings is that perhaps the views are reflective of standard business rhetoric and not an exception. Notwithstanding this, the research could use country, organisational size and industry as different cuts through which to investigate paradigm adherence. Also given the Gladwin, Kennelly, and Krause, (1995) scheme is nearly twenty years old it would perhaps be worthwhile reexamining the paradigm assumptions and how they could be operationalised in light of current research.

Notwithstanding the above, the findings and the expressed views of the interviewees imply that the organisations investigated are challenging conventional notions of organisational purpose; in this regard their views may be instructive towards new conceptions that enhance the pursuit of sustainable outcomes. In short, their rhetoric and their reality imply a new future normal. 


\section{References}

Andersson, L M, Bateman, T S, (2000) 'Individual Environmental Initiative:

Championing Natural Environmental Issues in US Business Organisations' Academy of Management Journal, Vol.43 No. 3, pp. 548-570.

Banerjee, SB (2003) 'Who sustains whose development? Sustainable Development and the Reinvention of Nature' Organization Studies, Vol. 24, pp. 143-180.

Bansal, P, Roth, K (2000) 'Why Companies Go Green: A Model of Ecological

Responsiveness' Academy of Management Journal, Vol. 43, No. 4, pp. 717-736.

Barter, N, Bebbington, J (2010) Pursuing Environmental Sustainability, Association of Chartered Certified Accountants, London

Bebbington, J., (2001) "Sustainable development: a review of the international development, business and accounting literature" Accounting Forum, Vol. 25, No. 2, pp. $128-157$.

Burrell, G, Morgan, G (1979, 2008 reprint), Sociological Paradigms and

Organisational Analysis, Aldershot, Ashgate Publishing, London.

Byrch, C, Kearins, K, Milne, M, Morgan, R (2007) 'Sustainable "what"? A cognitive approach to understanding sustainable development' Qualitative Research in Accounting and Management, Vol. 4, No. 1, pp. 26-52.

Catton, W, Dunlap, R (1980) 'A new ecological paradigm for post-exuberant sociology,' American Behavioural Scientist, Vol. 20, No. 1, pp. 15-47.

Colby, M E, (1991) 'Environmental management in development: the evolution of paradigms', Ecological Economics, Vol. 3, pp. 193-213.

Collison, D (2003) "Corporate propaganda: Its implications for accounting and accountability", Accounting, Auditing and Accountability Journal, Vol. 16, No. 3, pp. 853-886. 
Crompton, T (2008) 'Weathercocks and Signposts' A World Wildlife Fund Report published in April 2008 and available at:

http://www.wwf.org.uk/research centre/research centre results.cfm?uNewsID=222 4 (Accessed $20^{\text {th }}$ August 2009)

Crompton, T, Thorgersen, J (2009) 'Simple \& painless?' A World Wildlife Fund Report published in February 2009 and available at:

http://www.wwf.org.uk/research centre/research centre results.cfm?uNewsID=272

$\underline{8}$ (Accessed 20 ${ }^{\text {th }}$ August 2009)

Cummings, S (2005) Recreating Strategy. Sage, London.

Daly, H. E., (1996) Beyond Growth. Beacon Press, Boston.

Devereaux Jennings, P., D, Zandbergen, P., A. (1995) 'Ecologically Sustainable

Organizations: An Institutional Approach'. Academy of Management Review, Vol. 20, No. 4, pp. $1015-1052$.

Dryzek, J. (1997), The Politics of the Earth. Environmental Discourses, Oxford University Press, New York.

Dunlap, R E, Van Liere, K D (2008) 'The New Environmental Paradigm' The Journal of Environmental Education, Vol. 40, No.1, pp. 19-28 (reprint of article originally published in 1978).

- Citation: Pirages, D C, Ehrlich, PR, (1974) Social Response to Environmental Imperatives. Freeman, San Francisco.

Eckersley, R. (2003) Environmentalism and Political Theory: Towards an Ecocentric Approach, (reprint of 1992 edition), Routeledge, London.

Egri, C P, Herman, S (2000) 'Leadership in the North American Environmental Sector: Values, Leadership Styles, and Contexts of Environmental Leaders and their Organizations' Academy of Management Journal, Vol. 43, No. 4, pp. 571-604. Egri C P, Pinfield, LT (1999) 'Organizations and the Biosphere: Ecologies and 
Environments', 209-233 In Clegg, SR, Hardy, C and Nord, WR (eds) (1999) Managing Organizations Sage, London.

Ekins, P (2000) Economic Growth and Environmental Sustainability, Routledge, London.

Gladwin, T., N., Kennelly, J., J., Krause, T. S., (1995) 'Shifting Paradigms for Sustainable Development: Implications for Management Theory and Research.' Academy of Management Review, Vol.20, No. 4, pp. 874-907.

Godfrey, P. C, (2005) 'The Relationship between Corporate Philanthropy and Shareholder Wealth: A Risk Management Perspective'. Academy of Management Review, Vol. 30, No. 4, pp. 777-798.

Gopalkrishnan R I (1999) 'Business, Consumers and Sustainable Living in an Interconnected World: A Multilateral Ecocentric Approach' Journal of Business Ethics Vol. 20, pp. 273-288.

Gray, R, Bebbington, J, Walters, D, (1993) Accounting for the Environment, Paul Chapman Publishing, London.

Halme, M (1996) 'Shifting Environmental Management Paradigms in Two Finnish Paper Facilities: A Broader View of Institutional Theory' Business Strategy and the Environment, Vol. 5, pp. 94-105.

Hanna, M (1995) 'Environmentally responsible managerial behaviour: Is ecocentrism a prerequisite?' The Academy of Management Review, Vol. 20, pp. 796-799.

Citation: Pauchant, T. C., Fortier, I. (1990) 'Anthropocentric ethics in organizations, strategic management and the environment: A topology'. In P. Shrivastava \& R. B. Lamb (Eds.), Advances in strategic management, Vol. 6, pp. 99-114. JAI Press, Greenwich, CT.

Hawken, P. Lovins, A.B., Lovins, L. H. (2000) Natural Capitalism: The Next Industrial Revolution. Earthscan, London. 
Hoffman, AJ, Sandelands, LE (2005) 'Getting Right with Nature: Anthropocentrism, Ecocentrism, and Theocentrism,' Organization \& Environment, Vol. 18, pp. 141-162. IPCC, (2007, May) 'Working Group III contribution to the Intergovernmental Panel on Climate Change Fourth Assessment Report.' (page 3) Available:

http://www.ipcc.ch/ (Accessed 4th June 2007).

Jackson, T (2009) 'Prosperity without growth? The transition to a sustainable economy' Published by the UK Sustainable Development Commission.

Johnson, P C, (1996) 'Development of an Ecological Conscience: Is Ecocentrism a Prerequisite?' Academy of Management Review, Vol. 21, No. 3, pp. 607-611.

Jonas, H., (1984) The Imperative of Responsibility, Paperback edition, The University of Chicago Press, Chicago.

Katz, D., Kahn, R. L., (1966) The Social Psychology of Organizations, John Wiley and Sons, London.

Kilbourne, W. E., Beckmann S. C., Thelen, E., (2002) 'The role of the Dominant Social Paradigm in environmental attitudes a Multinational examination' Journal of Business Research, Vol. 55, pp. 193-204.

Kilbourne, W E, Carlson, L (2008) 'The Dominant Social Paradigm, Consumption and Environmental Attitudes: Can Macromarketing Education Help?' Journal of Macromarketing, Vol. 28, No. 2, pp. 106-121.

Kilduff, GJ, Anger Elenbein, H, Staw, BM (2010) 'The Psychology of Rivalry: A Relationally Dependent Analysis of Competition', Academy of Management Journal, Vol. 53, No. 5, pp. 943-969.

King, A. (1995) 'Avoiding Ecological Surprise: Lessons from Long Standing Communities'. Academy of Management Review, Vol. 20, No. 4, pp. 961-985. Kuhn, T., S., (1996) The Structure of Scientific Revolutions, 3rd ed. University of Chicago Press, Chicago. 
Lovelock, J. (2006) The Revenge of Gaia. Penguin Books, London.

Meadows, D., Randers, J., Meadows, D. (2005) Limits to Growth: The 30-Year Update. Earthscan, London.

Lozano, R (2007) 'Collaboration as a Pathway for Sustainability' Sustainable

Development, Vol. 15, pp. 370-381.

Lozano, R (2008) 'Developing collaborative and sustainable organisations' Journal of Cleaner Production, Vol. 16, pp. 499-509

Mebratu, D (1998) 'Sustainability and Sustainable Development: Historical and Conceptual Review' Environmental Impact Assessment Review, Vol. 18, pp. 493-520. Meima, R, (1996) 'Epistemological Problems and a Proposal for a Dichotomous Approach' The Academy of Management Review, Vol. 21, No. 4, pp. 914-917. Milbrath, LW (1984) Environmentalists: Vanguard for a New Society Albany: State University of New York Press.

Millennium Ecosystem Assessment 'MA Findings and MA Findings (Updated November 2005),' Available: http://www.millenniumassessment.org//en/Presentations.aspx (Accessed 8th January 2006).

Morgan, G (2006) Images of Organization, Sage Publications, London. Parrish, B (2007) 'Sustainability Entrepreneurship: Innovation in the Logics of Organizing' Conference Paper for the Corporate Responsibility Research Conference, July, University of Leeds.

Pauchant, T C, (1996) 'Cheese and Dessert or Cheese or Dessert? The Controversy over the Notion of Ecocentric Management' Academy of Management Review, Vol. 21 , No. 1 , pp. $11-12$.

Plaza-Úbeda, JA, Burgos-Jiménez, J, Vazquez, DA, Liston-Heyes, C (2007) 'The 'WinWin' Paradigm and Stakeholder Integration', Business Strategy and the Environment, Vol.18, No.8, pp. 487-499. 
Purser, R. E., Park, C., Montuori, A., (1995) 'Limits to Anthropocentrism: Toward an Ecocentric Organization Paradigm?' Academy of Management Review, Vol. 20, No. 4, pp. 1053-1089.

Purser, R. E., Montuori, A., (1996) 'Ecocentrism is in the Eye of the Beholder' Academy of Management Review, Vol. 21, No.3, pp. 611-613.

Schien, E (1992) Organizational Culture and leadership, Jossey-Bass, San Francisco. Scott, WR (1995) Institutions and organizations, Sage, London.

Sethi, SP (1995) 'Introduction to AMR's Special Topic Forum on Shifting Paradigms:

Societal Expectations and Corporate Performance' Academy of Management Review, Vol. 20, No.1, pp. 18-21.

Shafer, WE (2006) 'Social Paradigms and Attitudes Toward Environmental Accountability' Journal of Business Ethics, Vol. 65, pp. 121-147.

Shafritz, J M, Ott, J S (1992) Classics of Organization Theory, $3^{\text {rd }}$ edition, Brooks/Cole Publishing, California.

Shrivastava, P. (1995a) 'Ecocentric Management for a Risk Society'. Academy of Management Review, Vol. 20, No.1, pp. 118-137.

Shrivastava, P. (1995b) 'The Role of Corporations in Achieving Ecological Sustainability' Academy of Management Review, Vol. 20, No. 4, pp. 936-960.

Smith, C (2003) 'Strategy as Numbers'. In S. Cummings, D. Wilson (eds.) Images of Strategy. Blackwell, Oxford.

Starik, M., Rands, G. P., (1995) 'Weaving an Integrated Web: Multilevel and Multisystem Perspectives of Ecologically Sustainable Organizations.' Academy of Management Review, Vol. 20, No. 4, pp. 908-935.

Viederman, S. (1995), "Knowledge for sustainable development. What do we need to know?" in Trzyna, T.C. and Osborn, J. (Eds), A Sustainable World. Defining and Measuring Sustainable Development, International Center for the Environment and 
Public Policy (Published for IUCN), Sacramento, CA, pp. 36-43.

Whittington, R (1993) What is Strategy - and does it matter? London: Routledge

World Commission on Environment and Development (1987) Our Common Future,

Oxford University Press, Oxford.

Worldwatch Institute, (2004) State of the World. London: Norton and Company

World Wildlife Fund 'Living Planet Report 2006.' Available:

http://www.panda.org/news_facts/publications/living_planet_report/index.cfm

\section{NOTES}

\footnotetext{
' Sustainable development can be defined as "development which meets the needs of the present without compromising the ability of future generations to meet their own needs" (The World Commission on Environment and Development, 1987, p. 8). This definition has widespread acceptance, but there is significant debate about how such a vision can be achieved. Bebbington (2001) provides a summary of the background to the sustainable development debate and its relevance for business and the accounting literature. A historical review of the sustainable development concept can be found by referring to Mebratu
} (1998).

ii Anthropocentric paradigms are given various labels in the literature. For example; Egri and Pinfield (1999) use the label 'Dominant Social Paradigm', Shrivastava (1995a) uses the term 'traditional management paradigm,' Gladwin, Kennelly, and Krause, (1995) use the term 'Technocentrism' and Colby (1991) and Devereaux Jennings and Zandbergen (1995) use the term 'frontier economics.'

iii Hoffman and Sandelands (2005) discuss an alternative paradigm - theocentrism which draws upon humans' relationship with god.

iv Similarly, sustainability and sustainable development focus on future outcomes and as Dryzek (1997) outlines they cannot be "proven or demonstrated" (ibid, p. 123) rather they are "asserted" (ibid) or in short a "vision of the future" (Viederman, 1995, p. 37).

${ }^{\vee}$ Ecocentrism is "based on an ecologically informed philosophy of internal relatedness, according to which all organisms are not simply interrelated but also constituted by those environmental relationships" (Eckersley, 2003, p. 49). Similar to anthropocentric paradigm labels, ecocentric paradigms are given 
various labels. For example; Egri and Pinfield use the term 'Radical Environmentalism,' Colby (1991) and Devereaux Jennings and Zandbergen (1995) use the term 'deep ecology,' Purser, Park, and Montuori, (1995) use the term 'ecocentric responsibility paradigm' and Shrivastava (1995a) uses the term 'ecocentric management.'

vi Lozano (2008) has described the $20^{\text {th }}$ century as being the "Century of Self" (ibid, p. 500) where the focus is on the individual and this focus is reinforced by marketing and advertising.

vii With regards to ontology and epistemology this research can be difficult to place. If one were to use Burrell and Morgan's (1979) framework of sociological paradigms for social science research, it could be claimed that this research falls within a functionalist paradigm, ie it is realist, positivist, deterministic and nomothetic. Thus, it treats the social world as if its objective, results can be gathered and shared, in short patterns can be determined and conveyed, human nature is determined and methodologically the research is clearly testing a concept and set of questions with regularity. However in many regards this research also wishes to avoid placement and the categorisation as either subjective or objective in its treatment of social reality. Meima (1996) commented that invariably paradigm exploration ends up oscillating between "objectivism and subjectivism [and the leaning is towards] the epistemology of the soft human factor in a hard world" (Meima, 1996, p. 916). This research is congruent with Meima's (1996) comment and ideally would avoid any relations with Burrell and Morgan's (1979) framework or any other categorisation as subjective or objective - however perhaps that is unavoidable.

viii While noting that it can be argued that one may not be able to maximise, due to the cognitive limits of humans (Godfrey, 2005; Sharfritz and Ott, 1992). The aim of this question was to explore whether or not organisations intentionally sought a particular outcome that they knew not to be the maximum possible and whether or not they aimed to balance financial, environmental and social outcomes deliberately: an approach that Parrish (2007) describes as strategic satisficing.

ix The three USA organisations were seventh GENERATION, TerraCycle and Recycline, the Belgium organisation was Ecover.

${ }^{x}$ As indicated it should be noted that the interviews used questions informed by paradigms but these questions also allowed the interviewees to elucidate their views more generally. Thus the research was not solely focused on exploring paradigm adherence, rather it was in parochial terms hedging its bets and in this regard the study was exploratory.

xi This table highlights ten economic and psychological assumptions for technocentrism, sustaincentrism and ecocentrism. Some of these terms are likely to be clear given the wider discussion through the text. However to explain a few terms in particular, homo econimus alludes to whether humans make decisions based on monetary concerns only, whether we take a more balanced view (homo sapiens) or whether we 
are purely instinctual beings (homo animalist). For a more involved discussion of homo econimus please refer to Lozano (2007). Poverty alleviation assumptions refer to assumptions of whether poverty is alleviated by a growing economy and thus a growing economy lifts all participants or whether with reference to the ecocentric paradigm wealth needs to be actively redistributed.

xii The interviewee explained how the organisation had been set up to realise social justice, but had instead refocused on selling environmentally friendly cleaning products as this enabled financially viability.

xiii Future normal is a term that is referenced from Barter \& Bebbington, 2010. - A research report that used the same data as for this paper, but took a very different pass through the data and did not explore paradigm adherence. 
FIGURES FOR THE TEXT

Figure 1: Schematic Condensing the Results of Coding the Interviews to the Gladwin, Kennelly, and Krause

(1995) Paradigm Scheme

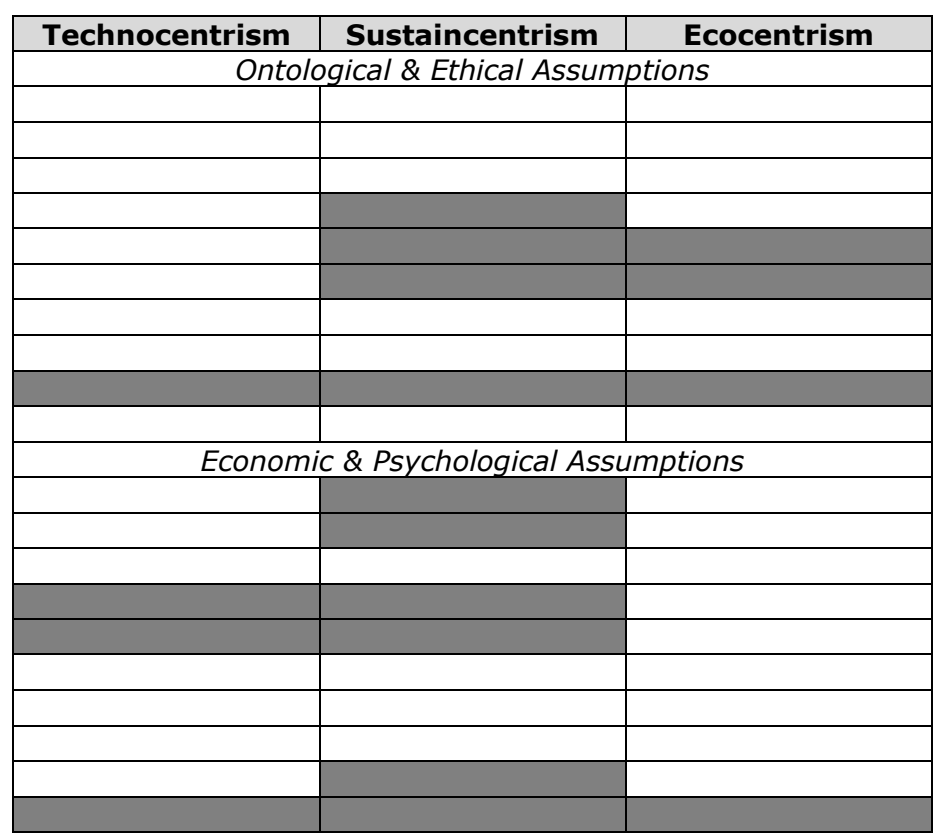


Table I: Alternative Environmental Paradigms

(Gladwin, Kennelly, and Krause, 1995:883)

\begin{tabular}{|c|c|c|c|}
\hline Key Assumptions & Technocentrism & Sustaincentrism & Ecocentrism \\
\hline \multicolumn{4}{|c|}{ Ontological \& Ethical } \\
\hline 1. Metaphor of earth & Vast Machine & Life support system & Mother/web of life \\
\hline 2. Perception of earth & Dead/passive & Home/managed & Alive/sensitive \\
\hline 3. System composition & Atomistic/parts & Parts and wholes & Organic/wholes \\
\hline 4. System structure & Hierarchical & Holoarchical & Heterarchical \\
\hline 5. Humans and nature & Disassociation & Interdependence & Indisassociation \\
\hline 6. Human role & Domination & Stewardship & Plain member \\
\hline 7. Value of nature & Anthropocentrism & Inherentism & Intrinsicalism \\
\hline 8. Ethical grounding & Narrow homocentric & Broad homocentric & Whole earth \\
\hline 9. Time/space scales & Short/near & Multiscale & Indefinite \\
\hline 10. Logic/Reason & Egoist-rational & Vision/network & Holism/spiritualism \\
\hline \multicolumn{4}{|c|}{ Scientific \& Technological } \\
\hline 1. Resilience of nature & Tough/robust & Varied/fragile & Highly vulnerable \\
\hline 2. Carrying capacity limits & No limits & Approaching & Already exceed \\
\hline 3. Population size & No problem & Stabilise soon & Freeze/reduce \\
\hline 4. Growth pattern & Exponential & Logistic & Hyperbolic \\
\hline 5. Severity of problems & Trivial & Consequential & Catastrophic \\
\hline 6. Urgency of solutions & Little/wait & Great/decades & Extraordinary/now \\
\hline 7. Risk orientation & Risk taking & Precaution & Risk aversion \\
\hline 8. Faith in technology & Optimism & Skepticism & Pessimism \\
\hline 9. Technological Pathways & Big/centralised & Benign/decoupled & Small/decentralised \\
\hline $\begin{array}{l}\text { 10. Human vs Natural } \\
\text { Capital }\end{array}$ & Full substitutes & Partial substitutes & Complements \\
\hline \multicolumn{4}{|c|}{ Economic \& Psychological } \\
\hline 1. Primary objective & Efficient allocation & Quality of life & Ecological integrity \\
\hline 2. The good life & Materialism & Postmaterialism & Antimaterialism \\
\hline 3. Human nature & Homo econimus & Homo sapient & Homo animalist \\
\hline 4. Economic structure & Free market & Green economy & Steady state \\
\hline 5. Role of growth & Good/necessary & Mixed/modify & Bad/eliminate \\
\hline 6. Poverty alleviation & Growth trickle & Equal opportunity & Redistribution \\
\hline 7. Natural capital & Exploit/convert & Conserve/maintain & Enhance/expand \\
\hline 8. Discount rate & High/normal & Low/complement & Zero/inappropriate \\
\hline 9. Trade orientation & Global & National & Bioregional \\
\hline 10. Political structure & Centralised & Devolved & Decentralised \\
\hline
\end{tabular}


Table II: Organisations Interviewed

\begin{tabular}{|c|c|}
\hline Organisation Name/Code & Organisation Name/Code \\
\hline $\begin{array}{l}\text { 1. Pillars of Hercules } \\
\text { (Organic food producer and retailer) }\end{array}$ & $\begin{array}{l}\text { 2. TerraCycle } \\
\text { (Producer of plant fertilisers from waste) }\end{array}$ \\
\hline $\begin{array}{l}\text { 3. biome lifestyle } \\
\text { (Online retailer of home wares) }\end{array}$ & $\begin{array}{l}\text { 4. Company A } \\
\text { (Producer of Fast Moving Consumer Goods) }\end{array}$ \\
\hline $\begin{array}{l}\text { 5. Beyond Skin } \\
\text { (Online retailer of shoes) }\end{array}$ & $\begin{array}{l}\text { 6. howies } \\
\text { (Producer/Retailer of clothes) }\end{array}$ \\
\hline $\begin{array}{l}\text { 7. Company B } \\
\text { (Producer and retailer of business and } \\
\text { consumer services) }\end{array}$ & $\begin{array}{l}\text { 8. Green Stationery Company } \\
\text { (Producer/Retailer of consumer and } \\
\text { business Stationery) }\end{array}$ \\
\hline $\begin{array}{l}\text { 9. Recycline } \\
\text { (Producer and Retailer of Consumer } \\
\text { Durables) }\end{array}$ & $\begin{array}{l}\text { 10. revolve } \\
\text { (Producer/Retailer of consumer and } \\
\text { business stationery and gifts) }\end{array}$ \\
\hline $\begin{array}{l}\text { 11. Green Building Store } \\
\text { (Producer/retailer of Building } \\
\text { Goods/Services) }\end{array}$ & $\begin{array}{l}\text { 12. Terra Plana } \\
\text { (Producer/Retailer of shoes) }\end{array}$ \\
\hline $\begin{array}{l}\text { 13. seventh GENERATION } \\
\text { (Producer of Business and Consumer } \\
\text { Cleaning Products) }\end{array}$ & $\begin{array}{l}\text { 14. By Nature } \\
\text { (Online retailer of natural products and } \\
\text { services) }\end{array}$ \\
\hline $\begin{array}{l}\text { 15. Ecover } \\
\text { (Producer of Business and Consumer } \\
\text { Cleaning Products) }\end{array}$ & $\begin{array}{l}\text { 16. belu } \\
\text { (Producer of bottled water) }\end{array}$ \\
\hline $\begin{array}{l}\text { 17. Company C } \\
\text { (Producer/Retailer of Business and } \\
\text { Consumer Cleaning Products) }\end{array}$ & $\begin{array}{l}\text { 18. Company D } \\
\text { (Producer/Retailer of Financial Products) }\end{array}$ \\
\hline $\begin{array}{l}\text { 19. People Tree } \\
\text { (Producer of Clothes) }\end{array}$ & $\begin{array}{l}\text { 20. BioRegional } \\
\text { (Sustainability focused charity and creator } \\
\text { of spin-off companies) }\end{array}$ \\
\hline $\begin{array}{l}\text { 21. Triodos Bank } \\
\text { (Financial Services to Businesses and } \\
\text { Consumers) }\end{array}$ & $\begin{array}{l}\text { 22. Suma } \\
\text { (Producer/Wholesales of Food) }\end{array}$ \\
\hline $\begin{array}{l}\text { 23. Company E } \\
\text { (Producer/retailer of wood products) }\end{array}$ & \\
\hline
\end{tabular}


Table III: Roles Interviewed

\begin{tabular}{|l|c|}
\hline \multicolumn{1}{|c|}{ Role } & Number \\
\hline Founder/Co-Founder & 14 \\
\hline Managing Director/CEO & 3 \\
\hline Executive Director - Operations & 1 \\
\hline Commercial/Marketing/General Manager & 3 \\
\hline Member/Co-worker & 2 \\
\hline $\begin{array}{l}\text { Director of Corporate Consciousness } \\
\text { /Concept Manager }\end{array}$ & 2 \\
\hline Total & 25 \\
\hline
\end{tabular}


Table IV: No. of Interviews Coded to Economic \& Psychological Assumptions of the Gladwin, Kennelly, and Krause, (1995) Paradigm Scheme

\begin{tabular}{|c|c|c|c|}
\hline Key Assumptions & Technocentrism & Sustaincentrism & Ecocentrism \\
\hline \multicolumn{4}{|c|}{ Economic \& Psychological } \\
\hline 1. Primary objective & Efficient allocation & $\begin{array}{c}\text { Quality of life } \\
19\end{array}$ & Ecological integrity \\
\hline 2. The good life & Materialism & $\begin{array}{l}5 \\
5\end{array}$ & Antimaterialism \\
\hline 3. Human nature & Homo econimus & Homo sapient & Homo animalist \\
\hline 4. Economic structure & $\begin{array}{c}16 \\
16\end{array}$ & $\begin{array}{c}\text { Green economy } \\
15\end{array}$ & Steady state \\
\hline 5. Role of growth & $\begin{array}{c}\text { Good/necessary } \\
\mathbf{8}\end{array}$ & $\begin{array}{l}\text { Mixed/modify } \\
13\end{array}$ & Bad/eliminate \\
\hline 6. Poverty alleviation & Growth trickle & Equal opportunity & Redistribution \\
\hline 7. Natural capital & Exploit/convert & Conserve/maintain & Ënhance/expand \\
\hline 8. $\quad$ Discount rate & High/normal & Low/complement & Zero/inappropriate \\
\hline 9. Trade orientation & "Gīobail"- & $\begin{array}{c}\text { National } \\
4\end{array}$ & Bioregional \\
\hline 10. Political structure & $\begin{array}{c}7 \\
7\end{array}$ & $\begin{array}{c}6 \\
6\end{array}$ & $\begin{array}{c}2 \\
2\end{array}$ \\
\hline
\end{tabular}


Table V: No. of Interviews Coded to Ontological \& Ethical Assumptions of the Gladwin, Kennelly, and Krause, (1995) Paradigm Scheme

\begin{tabular}{|c|c|c|c|}
\hline Key Assumptions & Technocentrism & Sustaincentrism & Ecocentrism \\
\hline \multicolumn{4}{|c|}{ Ontological \& Ethical } \\
\hline 1. Metaphor of earth & Vast Machine & Life support system & Mother/web of life \\
\hline 2. Perception of earth & Dead/passive- & Home/managed & Álive/sensitive \\
\hline 3. System composition & Atomistic/parts & Parts and wholes & Organic/wholes \\
\hline 4. System structure & Hierarchical & $\begin{array}{l}\text { Holoarchical } \\
\mathbf{2}\end{array}$ & Heterarchical \\
\hline 5. Humans and nature & Disassociation & $\begin{array}{c}1 \\
\mathbf{1 1}\end{array}$ & $\begin{array}{c}\text { Indisassociation } \\
\mathbf{2}\end{array}$ \\
\hline 6. Human role & Domination & $\begin{array}{c}\text { stewardship } \\
13\end{array}$ & $\begin{array}{c}1 \\
1\end{array}$ \\
\hline 7. Value of nature & Anthropocentrism & Inherentism & Intrinsicalism \\
\hline 8. $\quad$ Ethical grounding & Narrow homocentric & Broad homocentric & Whole earth \\
\hline 9. Time/space scales & $\begin{array}{c}\text { Short/near } \\
1\end{array}$ & $\begin{array}{c}\text { Múltiscale } \\
5\end{array}$ & $\begin{array}{c}\text { Indefinite } \\
1\end{array}$ \\
\hline 10. Logic/Reason & Egoist-rational & Vision/network & Holism/spiritualism \\
\hline
\end{tabular}

Table VI: Simple Practices the Organisations Engage in to Help Reinforce their Missions and embed Sustainability Awareness

\begin{tabular}{|l|c|}
\hline Area & Example \\
\hline Packaging & $\begin{array}{l}\text { Using recycled plastic bottles and applying recycled plastic } \\
\text { labels to these bottles. These bottles and labels are then used } \\
\text { as the package in which the product is sold (see } \\
\text { www.terracycle.net, for an example) } \\
\text { Using recycled packaging, i.e. suppliers' packaging } \\
\text { "we've never bought a piece of packaging in our life, } \\
\text { you know, we don't buy it, you know, we just use } \\
\text { everybody else's" (Green Stationery Company, Jay, } \\
\text { founder) } \\
\text { Using biodegradable plastic wrapping for catalogue mailings - } \\
\text { Suma } \\
\text { Using non-plastic recyclable jiffy bags for packaging products } \\
\text { for dispatch - biome Lifestyle }\end{array}$ \\
\hline
\end{tabular}




\begin{tabular}{|c|c|}
\hline Area & Example \\
\hline Employee Incentives & $\begin{array}{l}\text { - Employee pensions and company banking is done with ethical } \\
\text { funds/banks - BioRegional } \\
\text { - Company loans for upgrading employees' cars and houses to } \\
\text { reduce their carbon footprint - seventh Generation } \\
\text { - Mileage allowances for cycling to work - Green Building Store }\end{array}$ \\
\hline Operations & $\begin{array}{l}\text { - Not making to stock } \\
\text { "we no longer produce t-shirts people don't want to } \\
\text { buy" (howies, co-founder) } \\
\text { - Product Take back - Trade in policies for old clothes (howies) } \\
\text { - Dematerialisation } \\
\text { (discussing their recent store opening) "we're going to } \\
\text { email you the receipt rather than give you one, a paper } \\
\text { one" (howies, co-founder) }\end{array}$ \\
\hline $\begin{array}{l}\text { Trust and } \\
\text { Transparency }\end{array}$ & $\begin{array}{l}\text { - Transparent pay structures - BioRegional, Company E } \\
\text { - Trust } \\
\circ \text { "if you say you've got } 400 \mathrm{mls} \text { in, in the bottle, I don't } \\
\text { know exactly what the law says, but I think there's a } \\
\text { certain amount of latitude around the } 400 \mathrm{mls} \text {. We } \\
\text { don't have latitude around the } 400 \mathrm{mls}, 400 \mathrm{mls} \text {. Is the } \\
\text { minimum, right" (Company C, interviewee) } \\
\text { - Transparent bottles } \\
\text { "clear bottles means you can see what's in it,...warts } \\
\text { and all" (Company C, interviewee) }\end{array}$ \\
\hline Other & $\begin{array}{l}\text { - Heating the building with a wood powered boiler rather than } \\
\text { burning oil - Pillars of Hercules } \\
\text { - } \text { Planting trees to offset their carbon emissions - Suma } \\
\text { - Sustainable/eco-efficient head office rather than a "shed on an } \\
\text { industrial estate...important to us from the point of view of } \\
\text { meeting our prime objectives" (Company D, chief executive) } \\
\text { - Second hand Furniture } \\
\text { "when we buy furniture its second hand or its wood } \\
\text { from a sustainable source" (BioRegional, co-founder) }\end{array}$ \\
\hline
\end{tabular}

